\title{
Enhanced beta cell proliferation in mice overexpressing a constitutively active form of Akt and one allele of $p 21^{\text {Cip }}$
}

\author{
M. Blandino-Rosano $\cdot$ E. U. Alejandro • \\ A. Sathyamurthy • J. O. Scheys • B. Gregg • A. Y. Chen • \\ L. Rachdi • A. Weiss • D. J. Barker • A. P. Gould • \\ L. Elghazi • E. Bernal-Mizrachi
}

Received: 22 July 2011 / Accepted: 19 December 2011 / Published online: 12 February 2012

(C) Springer-Verlag 2012

\begin{abstract}
Aims/hypothesis The ability of pancreatic beta cells to proliferate is critical both for normal tissue maintenance and in conditions where there is an increased demand for insulin. Protein kinase B (Akt) plays a major role in promoting proliferation in many cell types, including the insulin-producing beta cells. We have previously reported that mice overexpressing a constitutively active form of $A k t\left(\mathrm{caAkt}^{T g}\right)$ show enhanced beta cell proliferation that is associated with increased protein levels of cyclin D1, cyclin D2 and cyclin-dependent kinase inhibitor $1 \mathrm{~A}\left(\mathrm{p} 21^{\mathrm{Cip}}\right)$. In the present study, we sought to assess the mechanisms responsible for augmented $\mathrm{p} 21^{\text {Cip }}$ levels in caAkt $t^{T g}$ mice and test the role of $\mathrm{p} 21^{\mathrm{Cip}}$ in the proliferative responses induced by activation of Akt signalling.
\end{abstract}

M. Blandino-Rosano and E. U. Alejandro contributed equally to this study.

Electronic supplementary material The online version of this article (doi:10.1007/s00125-012-2465-9) contains peer-reviewed but unedited supplementary material, which is available to authorised users.

M. Blandino-Rosano • E. U. Alejandro · J. O. Scheys · B. Gregg •

A. Y. Chen $\cdot$ L. Elghazi $\cdot$ E. Bernal-Mizrachi $(\bowtie)$

Department of Internal Medicine, Division of Metabolism,

Endocrinology and Diabetes, Brehm Center for Diabetes Research, University of Michigan Medical Center,

Ann Arbor, MI 48109-0678, USA

e-mail: ebernal@umich.edu

A. Sathyamurthy $\cdot$ L. Rachdi $\cdot$ A. Weiss $\cdot$ D. J. Barker $\cdot$

A. P. Gould

Department of Internal Medicine, Division of Endocrinology,

Metabolism and Lipid Research,

Washington University School of Medicine,

St Louis, MO, USA

Present address:

L. Rachdi

Inserm U845, Centre de Recherche Croissance et Signalisation,

Paris, France
Methods To gain a greater understanding of the relationship between Akt and p $21^{\mathrm{Cip}}$, we evaluated the mechanisms involved in the modulation of $\mathrm{p} 21^{\mathrm{Cip}}$ by Akt and the in vivo role of reduced $\mathrm{p} 21^{\mathrm{Cip}}$ in proliferative responses induced by Akt. Results Our experiments showed that Akt signalling regulates $p 21^{C i p}$ transcription and protein stability. $c a A k t^{T g} / p 21^{C i p+/-}$ mice exhibited fasting and fed hypoglycaemia as well as hyperinsulinaemia when compared with $c a A k t^{T g}$ mice. Glucose tolerance tests revealed improved glucose tolerance in $c a A k t^{T g} / p 21^{C i p+/-}$ mice compared with $c a A k t^{T g}$. These changes resulted from increased proliferation, survival and beta cell mass in $c a A k t^{T g} / p 21^{C i p+/-}$ compared with caAkt ${ }^{T g}$ mice.

Conclusions/interpretation Our data indicate that increased p21 ${ }^{\text {Cip }}$ levels in $c a A k t^{T g}$ mice act as a compensatory brake, protecting beta cells from unrestrained proliferation. These studies imply that $\mathrm{p} 21^{\mathrm{Cip}}$ could play important roles in the adaptive responses of beta cells to proliferate in conditions such as in insulin resistance.

Keywords Akt - Apoptosis - Beta cell signalling - Beta cells . Cell cycle · Glucose homeostasis · Insulin · Islets · p $21^{\text {Cip }}$.

Proliferation

\begin{tabular}{|c|c|}
\hline \multicolumn{2}{|c|}{ Abbreviations } \\
\hline Akt & Protein kinase $\mathrm{B}$ \\
\hline CDK & Cyclin-dependent kinase \\
\hline $\mathrm{P} 21^{\text {Cip }}$ & CDK-interacting protein, $\mathrm{CDK}$-inhibitor $1 \mathrm{~A}$ \\
\hline $\mathrm{CHX}$ & Cycloheximide \\
\hline GFP & Green fluorescent protein \\
\hline
\end{tabular}

\section{Introduction}

The capacity of the pancreatic beta cells to proliferate in response to insulin resistance is critical for glucose 
homeostasis and for preventing the progression to type 2 diabetes. Proliferation of mature beta cells is one of the components responsible for maintenance of beta cell mass in adult life [1]. Although it is widely accepted that reduction in functional beta cell mass is key in the pathogenesis of both type 1 and type 2 diabetes, there is little understanding of the mechanisms of how beta cells enter the cell cycle and progress to cell expansion. Many growth factors, including insulin and IGF-1, have been demonstrated to regulate beta cell mass [2-5]. The mechanisms downstream of these growth factor receptors are not fully mapped out, but it is widely accepted that the IRS2/phosphoinositide 3-kinase (PI3K)/protein kinase $\mathrm{B}(\mathrm{Akt})$ pathway plays a major role in the regulation of beta cell mass [6-10]. Indeed, numerous in vivo and in vitro studies point to the serine/threonine Akt kinase as a critical regulator of both proliferation and survival of beta cells [11-14]. We have previously demonstrated that Akt induces beta cell proliferation by promoting cyclin-dependent kinase 4 (CDK4) activity [15]. While there is some knowledge about the signalling pathways regulating beta cell proliferation, the downstream signalling pathways linking Akt to activation of CDK4 activity and beta cell $\mathrm{G}_{1}-\mathrm{S}$ transition are not completely understood.

Recent work from several laboratories has shown that CDK4 and cyclins D1 and D2 are critical regulators of proliferation and maintenance of beta cell mass after birth [16-19]. The CDK4-6/cyclin D complex is inhibited by the INK4 family (p16 ${ }^{\mathrm{INK} 4 \mathrm{a}}, \mathrm{p} 15^{\mathrm{INK} 5 \mathrm{~b}}, \mathrm{p} 18^{\mathrm{INK} 4 \mathrm{c}}$ and $\mathrm{p} 19^{\mathrm{INK} 4 \mathrm{~d}}$ ) of cell cycle inhibitors. $\mathrm{p} 21^{\mathrm{Cip}}$ belongs to the Cip/Kip family of inhibitors (p21 ${ }^{\text {Cip }}, \mathrm{p} 27^{\mathrm{Kip} 1}$ and $\mathrm{p} 57^{\mathrm{Kip} 2}$ ) and primarily inhibits CDK2. In addition to their cell cycle inhibitory function, $\mathrm{p} 27^{\mathrm{Kip}}$ and $\mathrm{p} 21^{\mathrm{Cip}}$ are also positive regulators of cyclin D/CDK4 complexes by promoting their assembly, stabilisation and activation in a concentration-dependent manner [20-23]. Understandably, repression of p $21^{\mathrm{Cip}}$ decreases formation of the CDK4/CDK6/cyclin D1 complex and results in impaired cell cycle progression in some systems $[24,25]$. While the importance of p27 in the regulation of beta cell mass in vivo has been studied, the role of $\mathrm{p} 21^{\mathrm{Cip}}$ in the regulation of the beta cell cycle is not completely understood [26-28]. Experiments in p21 ${ }^{\mathrm{Cip}}$-deficient mice have demonstrated that $\mathrm{p} 21^{\mathrm{Cip}}$ is not essential for maintaining beta cell function and cell cycle arrest in vivo [29]. In contrast, transgenic mice overexpressing $p 21^{C i p}$ (also known as $C d k n 1 a$ ) show decreased beta cell replication and induced hyperglycaemia [30]. Interestingly, increased p2 $1^{\text {Cip }}$ levels have also been demonstrated in proliferative states induced by hepatocyte growth factor, placental lactogen and IGF-I in human islets [31, 32]. Recently, we observed that $\mathrm{p} 21^{\text {Cip }}$ protein levels are increased in beta cells overexpressing Akt [15]. However, the mechanisms involved in the regulation of $\mathrm{p} 21^{\mathrm{Cip}}$ levels by Akt and the role of increased levels of this cell cycle inhibitor in beta cell proliferation are not understood.
In the present study, we set out to determine the mechanisms involved in the regulation of $\mathrm{p} 21^{\mathrm{Cip}}$ levels by Akt and to assess whether this protein plays a role in assembly of the cyclin D/CDK4 complex. The role of $\mathrm{p} 21^{\mathrm{Cip}}$ in cell cycle regulation in vivo was also evaluated by crossing transgenic mice overexpressing a constitutively active $A k t$ in beta cells with mice deficient with $\mathrm{p} 21^{\mathrm{Cip}}$. These experiments showed that Akt regulates $\mathrm{p} 21^{\mathrm{Cip}}$ levels by increasing its stability and altering its subcellular localisation. Taken together, these in vivo studies suggest that $\mathrm{p} 21^{\mathrm{Cip}}$ acts as a compensatory brake on the mitogenic effects of Akt signalling.

\section{Methods}

Generation of $\mathrm{caAkt}^{\mathrm{Tg}} / \mathrm{p} 21^{\mathrm{Cip}-/-}$ intercrosses Mice overexpressing constitutively active $A k t 1$ in beta cells $\left(c a A k t^{T g}\right)$ are in a C57BL/6J background and have been described previously [12]. $p 21^{\text {Cip- } /-}$ mice were obtained from The Jackson Laboratory (strain B6;129S2 and stock number 003263). Littermate animals used for the study were obtained by generating $\mathrm{caAkt} \mathrm{Tg}^{\mathrm{T}} / \mathrm{p} 21^{\mathrm{Cip}+/-}$ mice first followed by crossing these mice to $p 21^{C i p+/-}$. This breeding scheme generates the following genotypes: $c a A k t^{T g} / p 21^{C i p---}, \mathrm{caAkt}^{T g} / \mathrm{p} 21^{\mathrm{Cip+l-}}$, $p 21^{\text {Cip-l- }}, p 21^{\text {Cip+l- }}$ and $p 21^{C i p+/+}$. However, we were unable to obtain a sufficient number of $c a A k t^{T g} / p 21^{C i p-l-}$ and the analyses in these studies is limited to the other genotypes. Littermate controls and experimental animals were males on a mixed background. All procedures were performed in accordance with the animal studies committees of the University of Michigan and Washington University.

MIN6 cells and islets isolation MIN6 cells were stably transfected with a lentivirus containing a constitutively active Akt mutant (MIN6 ${ }^{\text {caAkt }}$ ) and cultured as described previously [33, 34]. MIN6 cells were infected with lentiviral vector containing the constitutively active Akt mutant and selected with G418. The caAkt1 used in this construct lacks the pleckstrin homology domain (Akt $\Delta 4-129)$ and contains an N-terminal Src myristoylation signal (myrAkt $\Delta 4-129)$ along with a haemagglutinin tag and was cultured as described previously [33, 34]. Pancreatic islets from wild-type and $\mathrm{caAkt}^{T g}$ mice were isolated by collagenase treatment as described previously [12]. On the morning following isolation, islets were hand picked, lysed and subjected to immunoprecipitation or immunoblotting analysis.

Cycloheximide treatment of MIN6 cells and islets MIN6 and $\mathrm{MIN}^{\text {caAkt }}$ cells were harvested after incubation in DMEM containing $25 \mathrm{mmol} / 1$ glucose, with 10\% FBS (Invitrogen, Carlsbad, CA, USA) and cycloheximide (CHX; $12.5 \mu \mathrm{g} / \mathrm{ml}$ ) (Sigma, St Louis, MO, USA) for $0,0.5,1,2,4,6$ or $8 \mathrm{~h}$. The cells were lysed using a lysis buffer $(125 \mathrm{mmol} / 1$ Tris, $\mathrm{pH} 7$, 
$2 \%$ SDS, $1 \mathrm{mmol} / 1$ dithiothreitol) containing a protease inhibitor cocktail (Roche Diagnostics, Mannheim, Germany) and sonicated for $15 \mathrm{~s}$. For islet experiments, islets were cultured in RPMI containing CHX $(12.5 \mu \mathrm{g} / \mathrm{ml})$ for 0 or $1 \mathrm{~h}$. Islet lysates were also processed under the same conditions as described for MIN6 cells. For each sample, $80 \mu \mathrm{g}$ of total lysate was subjected to immunoblotting as described below using the following antibodies: $\mathrm{p} 21^{\mathrm{Cip}}$, actin and tubulin.

Western blotting and immunoprecipitation For immunoblotting, $80 \mu \mathrm{g}$ total protein was used for probing $\mathrm{p} 21^{\mathrm{Cip}}$ in cell lysates as well as pancreatic islet lysates ( 200 islets). Protein was separated by $15 \%$ SDS polyacrylamide gel electrophoresis. Membranes were blocked in 5\% non-fat milk for $1 \mathrm{~h}$ at room temperature and incubated with primary antibody overnight. The antibodies used were: 21 $^{\text {Cip }}$ (SX118; BD Biosciences, Franklin Lakes, NJ, USA); phospho-glycogen synthase kinase 3-beta (GSK3 $\beta$ ) (Ser9; Cell Signaling, Danvers, MA, USA); CDK4 and CDK2 (c-22 and sc-163, respectively; Santa Cruz Biotechnology, CA, USA). The housekeeping genes actin and tubulin were from Sigma. Cell cycle components were assessed using antibodies as described [35].

Immunoprecipitation experiments were carried out according to the instructions of the ProteinG Immunoprecipitation kit (Sigma). For each sample, $300 \mu \mathrm{g}$ of total protein was immunoprecipitated with $2 \mu \mathrm{g}$ of either anti-CDK2 (sc-163) or antiCDK4 (c-22) antibody and $50 \mu \mathrm{l}$ of protein G Sepharose beads (Sigma). The immunoprecipitated beads were washed and treated with $\times 2$ SDS sample buffer, and heated at $95^{\circ} \mathrm{C}$ for $10 \mathrm{~min}$. These samples were then separated on a $15 \%$ SDS gel by polyacrylamide gel electrophoresis and probed for the protein of interest. In vitro CDK4 kinase assays were performed as described [33]. All immunoblotting images were developed using an Amersham ECL plus western blotting detection system (GE Healthcare, Piscataway, NJ, USA) and processed in Alpha Innotech (San Leandro, CA, USA) gel imager. Bands were quantified using Spot Denso, Alpha Ease Fluor Chem SP (Alpha Innotech).

Quantitative real-time PCR Total RNA was isolated using RNeasy (Qiagen, Valencia, CA, USA). cDNA synthesis was performed using random hexamers and it was reverse transcribed using Superscript II (Invitrogen) according to the manufacturer's protocol. Real-time PCR was performed on an ABI 7000 sequence detection system using Taq-man gene expression assays (Applied Biosystems, Foster City, CA, USA). Primers were purchased from Applied Biosystems.

Islet morphometry, $p 21^{\text {Cip }}$ subcellular localisation, proliferation and TUNEL analysis Paraformaldehyde-fixed pancreatic tissues were embedded in paraffin using standard techniques. Sections were deparaffinised, rehydrated and incubated with blocking solution as previously described
[12]. Sections were incubated overnight at $4^{\circ} \mathrm{C}$ with antibodies against insulin (Linco Research, St Charles, MO, USA), p21 Cip (Santa Cruz Biotechnology and BD Biosciences), followed by secondary antibodies conjugated to FITC (Jackson Immunoresearch, West Grove, PA, USA). DAPIcontaining mounting media (Vector Laboratories, Burlingame, CA, USA) was added to coverslips. Beta cell mass assessment was performed by point counting morphometry from five insulin-stained sections $(5 \mu \mathrm{m})$ separated by $200 \mu \mathrm{m}$ using NIH Image J software (v1.43f freely available at http://rsb.info.nih.gov/ij/index.html) as described [12]. Cell proliferation and apoptosis were analysed using Ki67 and TUNEL (Millipore) staining. TUNEL-positive and proliferating cells were identified by co-staining for TUNEL or antigen identified by monoclonal antibody Ki 67 (Ki67) and insulin. At least 1000-3000 stained cells were counted from each animal. For cell imaging of p21 ${ }^{\text {Cip }}$ in vitro, MIN6 and MIN6 ${ }^{\text {caAkt }}$ cells were allowed to attach onto coverslips and left to grow overnight before fixing with $4 \%$ paraformaldehyde at room temperature for $10 \mathrm{~min}$, then permeabilising for 10 min with $0.1 \%$ Triton- $X$ as previously described [36]. Three independent cultures were analysed. A cell was considered to have positive nuclear $\mathrm{p} 21^{\mathrm{Cip}}$ staining when $\sim 80$ $90 \%$ staining was localised in the nucleus. The number of positive cells was calculated using Image J.

Metabolic studies-glucose, insulin and intraperitoneal glucose tolerance test Fasting glucose levels were measured after an overnight fasting using an AccuChek II glucometer (Roche Diagnostics, Indianapolis, IN, USA). Fed glucose levels were obtained at the same time in the morning of each day. Glucose and insulin tolerance tests were performed by intraperitoneal delivery of $2 \mathrm{~g} / \mathrm{kg}$ glucose or $0.75 \mathrm{U} / \mathrm{kg}$ insulin (Humalog, Eli Lilly, Indianapolis, IN, USA) to mice after $12 \mathrm{~h}$ fasting. Blood glucose was monitored for $2 \mathrm{~h}$ after glucose or insulin delivery. Plasma insulin levels were measured using rat insulin ELISA kit (Crystal Chem, Chicago, IL, USA).

Statistical analysis All data are represented as the mean \pm SEM from at least three independent experiments unless otherwise indicated. Data were analysed by Student's $t$ test or ANOVA followed by post hoc analysis, where appropriate. In some experiments, Student's paired $t$ test was used. Results were considered statistically significant when $p<0.05$.

\section{Results}

Akt signalling regulates $p 21^{\text {Cip }}$ transcription and protein stability Previous experiments in transgenic mice overexpressing a constitutively active Akt mutant in beta cells $\left(\mathrm{caAkt}^{T g}\right)$ demonstrated that islets from these mice exhibit increased $p 21^{C i p}$ mRNA and protein levels [15]. To begin to 
assess the relationship of Akt and $\mathrm{p} 21^{\mathrm{Cip}}$, we first established an in vitro system using MIN6 cells producing green fluorescent protein (GFP) (control) or overexpressing a constitutively active form of Aktl (MIN6 ${ }^{\text {caAkt }}$ ). These cells exhibit increased Akt1, 2 and 3 (compared with augmented Akt1 and Akt2 in $c a A k t^{T g}$ islets) and elevated total activity, demonstrated by phosphorylation of GSK3 $\beta$ (electronic supplementary material [ESM] Fig. 1a,d). Similar to $c a A k t^{T g}$ mice, this cell line exhibits augmented proliferation resulting from increased levels of cyclin D2, D3 and CDK4 activity [33] (ESM Fig. 1 and data not shown). In addition, MIN6 ${ }^{\text {caAkt }}$ cells express higher levels of $p 21^{\text {Cip }}$ mRNA compared with controls (Fig. 1a). The changes in $p 21^{\text {Cip }}$ mRNA levels are similar to those observed in islets from $c a A k t^{T g}$ mice [15]. To further determine the contribution of stability on steady-state mRNA levels, we treated MIN6 and MIN6 ${ }^{\text {caAkt }}$ cells with the transcription inhibitor actinomycin D. The half-life of $p 21^{C i p}$ mRNA expression was significantly decreased in MIN6 $6^{\text {caAkt }}$ cells, suggesting that Akt induces $p 21^{C i p}$ mRNA levels mainly by transcriptional regulation (Fig. 1a). We next investigated $\mathrm{p} 21^{\mathrm{Cip}}$ protein in MIN6 ${ }^{\text {caAkt }}$ cells and observed that these cells exhibited increased levels of $\mathrm{p} 21^{\mathrm{Cip}}$ compared with control cells (Fig. 1c). The extent to which protein stability contributes to elevated $p 21^{C i p}$ expression was then determined by culturing MIN6 cells and islets with CHX. We observed that p2 $1^{\text {Cip }}$ protein levels decreased at a faster rate in control cells compared with MIN6 ${ }^{\text {caAkt }}$ (Fig. 1d). Figure 1e shows the quantification of $\mathrm{p} 21^{\text {Cip }}$ levels adjusted to the levels of this cell cycle inhibitor before CHX in MIN6 $6^{\text {caAkt }}$ and controls. To confirm that Akt regulates $\mathrm{p} 21^{\mathrm{Cip}}$ protein stability in an ex vivo system, we performed similar experiments in islets from $c a A k t^{T g}$ mice. In agreement with our findings in MIN6 cells, p21 ${ }^{\text {Cip }}$ protein appears more stable in the presence of Akt signalling activation (Fig. 1f).

Altered subcellular localisation of $p 21^{\text {Cip }}$ in cells overexpressing Akt The subcellular localisation of $\mathrm{p} 21^{\mathrm{Cip}}$ has been implicated to play a role in its stability and function [37]. Therefore, we tested whether the subcellular localisation of

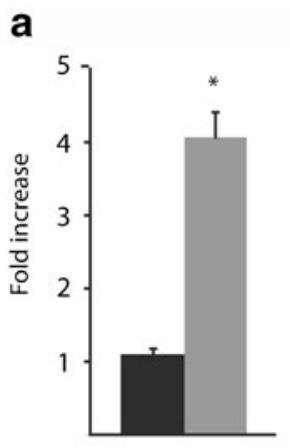

b

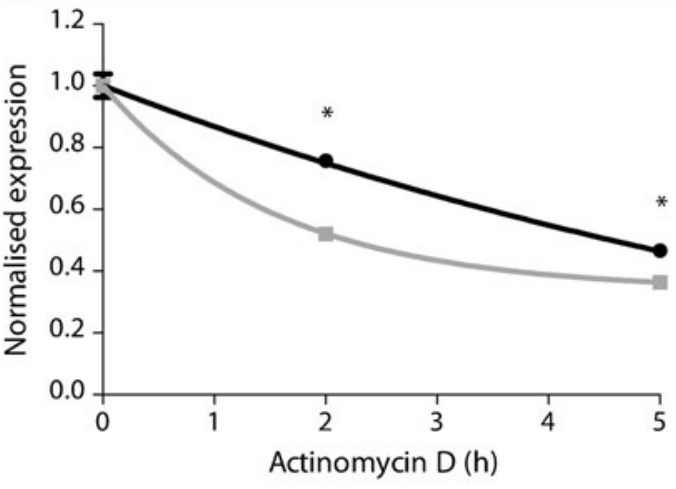

C
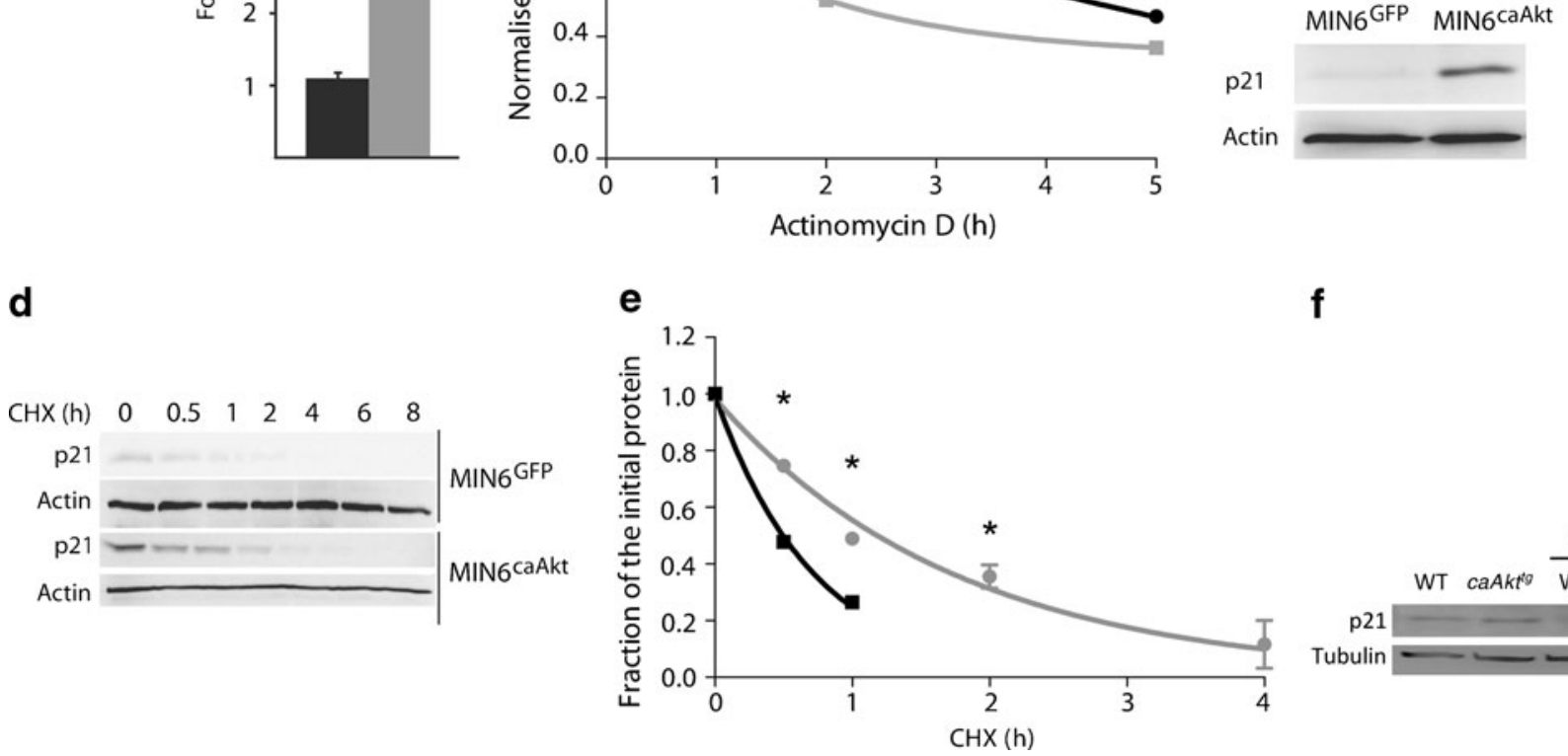

f

Fig. 1 Akt regulates p21 Cip levels by transcriptional regulation and protein stability. a Assessment of $p 21^{\text {Cip }}$ mRNA levels in MIN6 ${ }^{\mathrm{GFP}}$ and MIN6 ${ }^{\text {caAkt }}$ cells using TaqMan RT-PCR. b $p 21^{\text {Cip }}$ mRNA stability assays from MIN6 and MIN6 ${ }^{\text {caAkt }}$ cells treated with $5 \mu \mathrm{g} / \mathrm{ml}$ actinomycin D in $5.5 \mathrm{mmol} / 1$ glucose. Half-lives were calculated using GraphPad Prism Software: MIN6 ${ }^{\mathrm{GFP}} t_{1 / 2}=6.2 \mathrm{~h} ; \mathrm{MIN}^{\mathrm{caAkt}} t_{1 / 2}=1.1 \mathrm{~h}$; c Immunoblotting for $\mathrm{p} 21^{\mathrm{Cip}}$ in MIN6 $6^{\mathrm{GFP}}$ and MIN6 $6^{\mathrm{caAkt}}$ cells. d p $21^{\text {Cip }}$ protein stability assessed by immunoblotting for $\mathrm{p} 21^{\text {Cip }}$ and actin in $\mathrm{MIN6}^{\mathrm{GFP}}$ and MIN6 ${ }^{\text {caAkt }}$ cells cultured with $12.5 \mu \mathrm{g} / \mathrm{ml}$ CHX for $0,0.5,1,2,4,6$ and $8 \mathrm{~h}$. e Quantification of $\mathrm{p} 21^{\text {Cip }}$ stability experiments in MIN6 ${ }^{\mathrm{GFP}}$ and MIN6 ${ }^{\text {caAkt }}$ cells. Protein bands for $\mathrm{p} 21^{\mathrm{Cip}}$ were quantified and normalised to the levels in cells at time $0 . \mathbf{f} \mathrm{p} 21^{\mathrm{Cip}}$ protein stability assessed by immunoblotting for $\mathrm{p} 21^{\mathrm{Cip}}$ and tubulin in islets cultured with $12.5 \mu \mathrm{g} / \mathrm{ml} \mathrm{CHX}$ for $1 \mathrm{~h}$. Data are presented as mean \pm SEM of at least three independent experiments $(n \geq 3){ }^{*} p<0.05$. In graphs: black line, MIN6 ${ }^{\mathrm{GFP}}$; grey line, MIN6 ${ }^{\mathrm{caAkt}}$. WT, wild type 
p2 $1^{\text {Cip }}$ is altered in cells overexpressing Akt. We observed that staining for $\mathrm{p} 21^{\mathrm{Cip}}$ in control MIN6 cells was predominantly nuclear compared with MIN6 ${ }^{\text {caAkt }}$ cells (Fig. 2a, b). On the other hand, MIN6 ${ }^{\text {caAkt }}$ cells exhibited both nuclear and cytoplasmic staining but cytoplasmic p2 ${ }^{\text {Cip }}$ staining appeared to be more robust (Fig. 2a, b). Assessment of $\mathrm{p} 21^{\mathrm{Cip}}$ staining in pancreases from $\mathrm{caAkt} t^{\mathrm{Tg}}$ and control mice demonstrated that insulin-positive cells overexpressing Akt exhibit a predominantly cytoplasmic localisation of $\mathrm{p} 21^{\mathrm{Cip}}$ compared with a more diffuse staining observed in wildtype islet cells (Fig. 2c). These data suggest that p2 $1^{\text {Cip }}$ subcellular localisation is altered in cells with elevated Akt signalling.

MIN6 cells and islets overexpressing the caAkt mutant exhibit high levels of $221^{\text {Cip }}$ bound to CDK4 and CDK2 We next set out to determine whether the increase in $\mathrm{p} 21^{\mathrm{Cip}}$ levels via Akt modulation leads to greater assembly of the cyclin $\mathrm{D} / \mathrm{CDK} 4$ complex or whether $\mathrm{p} 21^{\mathrm{Cip}}$ preferentially binds to the cyclin $\mathrm{E}$ or $\mathrm{A} / \mathrm{CDK} 2$ complex. To study this possibility, we first assessed the proportion of $\mathrm{p} 21^{\mathrm{Cip}}$ bound a

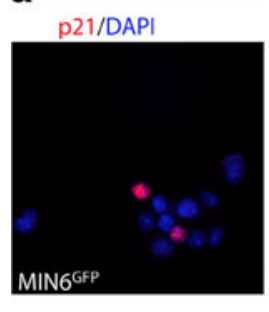

C
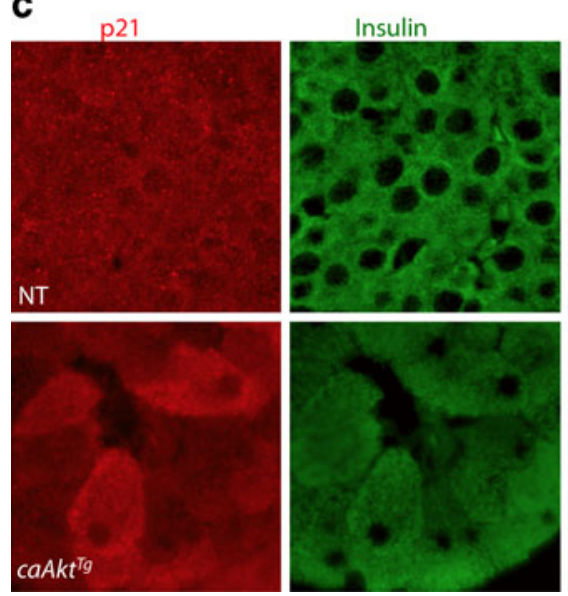

b

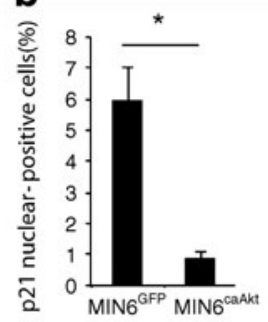

p21/insulin
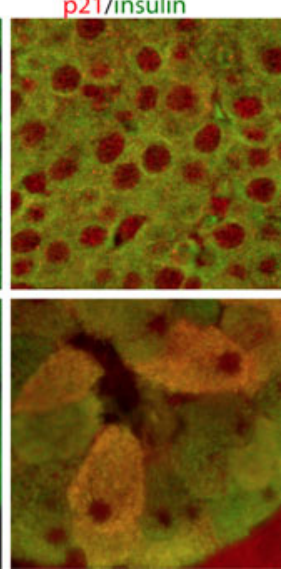

Fig. 2 Altered subcellular localisation of $\mathrm{p} 21^{\mathrm{Cip}}$ in cells overexpressing Akt. a Representative immunofluorescence imaging for $\mathrm{p} 21^{\mathrm{Cip}}$ (red) and nuclear staining with DAPI (blue) in MIN6 and MIN6 $6^{\text {caAkt }}$ cells. b Quantification of p21 ${ }^{\text {Cip }}$ subcellular localisation. c Immunofluorescence imaging of endogenous $\mathrm{p} 21^{\mathrm{Cip}}$ in pancreatic islets from nontransgenic and caAkt mice. Staining of $\mathrm{p} 21^{\mathrm{Cip}}$ is shown in red and insulin in green. Data are presented as mean \pm SEM of at least three independent experiments $(n \geq 3) .{ }^{*} p<0.05$. NT, non-transgenic to CDK4 and CDK2 in MIN6 cells and islets with activation of Akt signalling. Immunoprecipitation of CDK4 followed by immunoblotting for $\mathrm{p} 21^{\text {Cip }}$ demonstrated a twofold increase in $\mathrm{p}^{\text {Cip }}$ bound to CDK4 in MIN6 ${ }^{\text {caAkt }}$ (Fig. 3a). Similar experiments performed in isolated islets from wildtype and caAkt ${ }^{T g}$ mice also demonstrated twofold increase in $\mathrm{p} 21^{\mathrm{Cip}}$ bound to CDK4 (Fig. 3b). The increase in the CDK4/p21 ${ }^{\text {Cip }}$ complex appeared to follow the same cellular distribution as $\mathrm{p} 21^{\mathrm{Cip}}$, with a more robust cytoplasmic fraction and a less abundant component in the nucleus (ESM

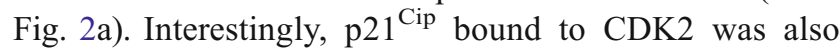
increased in MIN6 ${ }^{\text {caAkt }}$ cells and in islets from caAkt ${ }^{T g}$ mice (Fig. 3c,d). These studies suggest that $\mathrm{p} 21^{\mathrm{Cip}}$ is an integral component of the cyclin $\mathrm{D} / \mathrm{CDK} 4$ and cyclin $\mathrm{E}$ or A/CDK2 complexes in beta cells and that Akt signalling regulates the formation of these complexes. The functional effect of increased $\mathrm{p} 21^{\mathrm{Cip}}$ localised to these complexes in beta cell proliferation and mass was then assessed in vivo. a
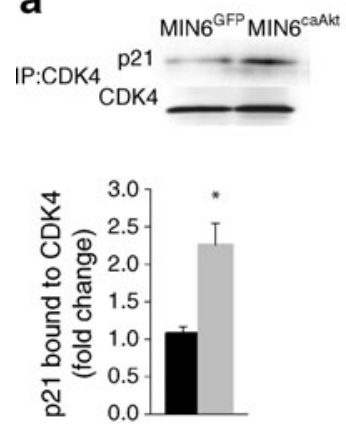

b
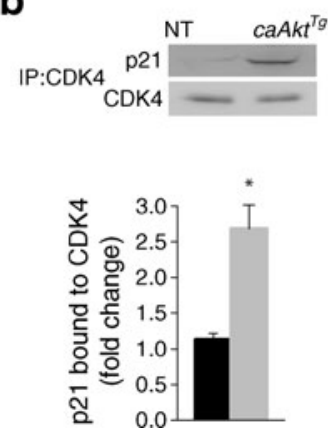
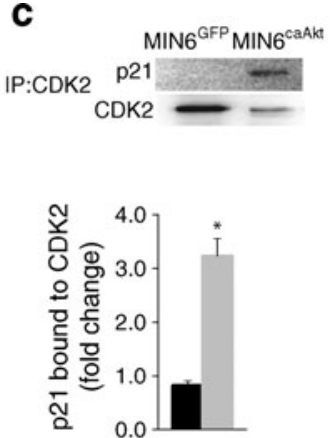

d
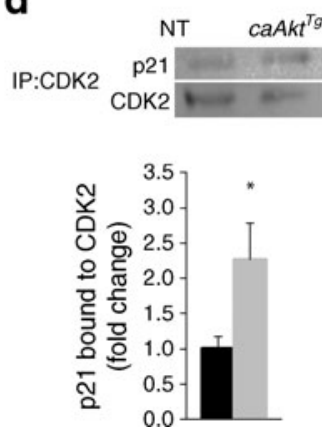

Fig. 3 Increased p21 ${ }^{\text {Cip }}$ levels bound to CDK4 and CDK2 complex in MIN6 cells and islets with activation of Akt signalling. a,b Assessment of $\mathrm{p} 21^{\text {Cip }}$ bound to the CDK4 complex in MIN6 (a) and in islets (b). c,d Assessment of $\mathrm{p} 21^{\mathrm{Cip}}$ bound to the CDK2 complex in MIN6 (c) and in islets (d). Cell lysates from MIN6 ${ }^{\mathrm{GFP}}$ and MIN6 ${ }^{\mathrm{caAkt}}$ or islet lysates from non-transgenic and $c a A k t^{T g}$ were immunoprecipitated with CDK4 or CDK2 antibodies followed by immunoblotting for $\mathrm{p} 21^{\text {Cip }}$. Quantification of $\mathrm{p} 21^{\text {Cip }}$ levels bound to CDK4 (a,b) and CDK2 (c,d). Immunoblotting for CDK4 and CDK2 were used as controls. Data are presented as mean $\pm \mathrm{SEM} ; n \geq 3 ; * p<0.05$. In graphs, black bars, non-transgenic; grey bars, caAkt ${ }^{T g}$. IP, immunoprecipitated; NT, non-transgenic 
Metabolic assessment of $p 21^{C i p+/ /} / c a A k t^{T g}$ mice To assess whether the in vivo increase in $p 21^{C i p}$ mRNA expression and protein level plays a role as a cell cycle inhibitor or promotes proliferation by favouring the assembly of the cyclin $\mathrm{D} / \mathrm{CDK} 4$ complex, we crossed caAkt ${ }^{T g}$ mice with mice deficient in $p 21^{\text {Cip }}$. The effects of decreased $\mathrm{p} 21^{\text {Cip }}$ levels on glucose metabolism in $\mathrm{caAkt}^{T g}$ mice were then analysed in blood samples from 3-4-month-old mice in the fasted and fed states. Body weights among the different groups were comparable (Fig. 4a). No differences were observed in fasting or fed blood glucose levels between $p 21^{\text {Cip }+/+}, p 21^{\text {Cip }+/-}$ and $p 21^{\text {Cip-/- }}$ mice (Fig. $4 b, d)$. In contrast to the normal fasting and fed glucose levels in $c a A k t^{T g} / p 21^{C i p+/+}$ mice, $c a A k t^{T g} / p 21^{C i p+/-}$ mice exhibited decreased blood glucose levels (Fig. 4b,d). Assessment of insulin values demonstrated that $p 21^{\mathrm{Cip}+/+}$, $p 21^{\text {Cip }+/-}$ and $p 21^{\text {Cip-l- }}$ mice exhibited comparable insulin levels in the fasting and fed states (Fig. 4c,e), yet serum fasting and fed insulin values of $c a A k t^{T g} / p 21^{C i p+/+}$ mice were elevated when compared with the non-transgenic groups (Fig. $4 \mathrm{c}$, e). caAkt ${ }^{T g} / p_{21}{ }^{C i p+/-}$ mice exhibited a significant increase in fasting insulin levels compared to $c a A k t^{T g} / p 21^{C i p+/+}$ mice (Fig. 4c). These results indicate that fasting serum insulin levels are increased in $c a A k t^{T g}$ mice lacking one allele or deficient in $p 21^{C i p}$. We were unable to obtain sufficient number of $c a A k t^{T g} / \mathrm{p} 21^{C i p-/-}$ for these experiments.

To determine the alterations in glucose handling in these mice, we performed intraperitoneal glucose tolerance tests in 34-month-old mice. The glucose tolerance values in $p 21^{\mathrm{Cip}+/+}$, $p 21^{\mathrm{Cip}+/-}$ and $p 21^{\mathrm{Cip-l-}}$ mice were comparable (Fig. 4f). As described previously, $\mathrm{caAkt}^{T g}$ animals exhibited improved glucose tolerance at 30 and $60 \mathrm{~min}$ after glucose injection (Fig. 4f). As shown in Fig. 4b, fasting glucose levels were lower in $c a A k t^{T g} / p 21^{C i p+l-}$ mice. Glucose tolerance in $c a A k t^{T g}$ mice lacking one allele of $p 21^{C i p}$ was improved when compared that of non-transgenic group. Interestingly, glucose levels at 30 and $60 \mathrm{~min}$ after glucose injection were lower in $\mathrm{caAkt}^{T g} / \mathrm{p} 21^{\mathrm{Cip+/-}}$ mice when compared with $c a A k t^{T g}$ mice (Fig. 4f). These data suggest that a reduction in $p 21^{C i p}$ levels significantly improves glucose tolerance in $c a A k t^{T g}$ mice.

Deletion of one allele of $221^{\text {Cip }}$ enhances beta cell mass in $\mathrm{caAkt}^{T g}$ mice The results of the metabolic studies showed that a decrease in $\mathrm{p} 21^{\mathrm{Cip}}$ levels alters the $c a A k t^{T g}$ phenotype

Fig. 4 Metabolic assessment of $p 21^{\text {Cip-/- }}$ and $c a A k t^{T g}$ intercross. a Body weight of 3-month-old male mice. Fasting glucose (b) and insulin (c) measurements were performed on overnight-fasted 34 month-old male non-transgenic mice or $c a A k t^{T g}$ mice containing two alleles $\left({ }^{+/+}\right)$or one allele $\left(^{+/}\right)$of $p 21^{\text {Cip }}$. d,e Random glucose and insulin levels obtained in the same group and age of mice. $\mathbf{f}$ Intraperitoneal glucose tolerance tests were performed on the same group of mice. Data are presented as mean $\pm \operatorname{SEM}(n=8-10) .{ }^{*} p<0.05$ compared with $p 21^{\mathrm{Cip}+/+} ;{ }^{\dagger} p<0.05$ compared with $c a A k t^{T g} / p 21^{\mathrm{Cip}+/+} \cdot p 21^{\mathrm{Cip}+/+}$, grey circle; $p 21^{\mathrm{Cip}+/-}$, grey square; $p 21^{\mathrm{Cip}-1-}$, grey triangle; caAkt ${ }^{T g}$, black triangle; and $c a A k t^{T g} / p 21^{\mathrm{Cip}^{+1}-}$, black square. NT, non-transgenic

and suggest that beta cell mass could be responsible for these observations. The histological appearance of the pancreas and quantification of beta cell mass were then assessed by islet morphometry. In adult pancreases, p $21^{\text {Cip+/- }}$ and

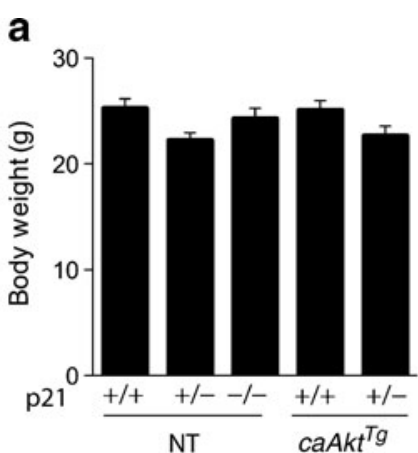

b

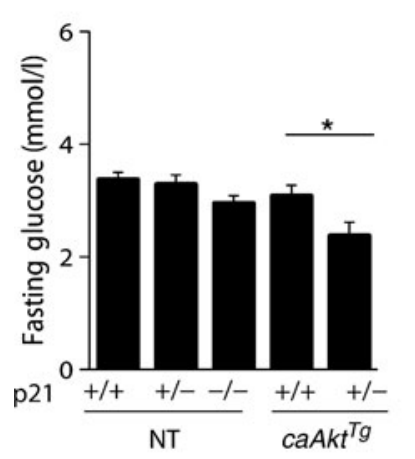

d

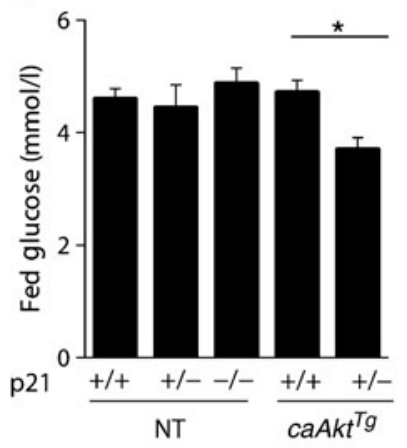

C

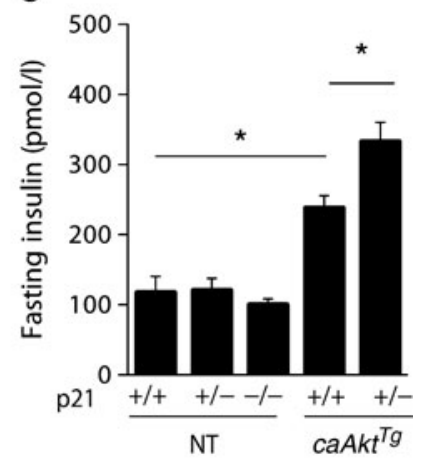

e

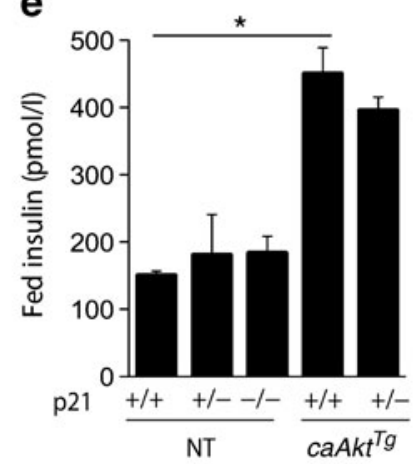

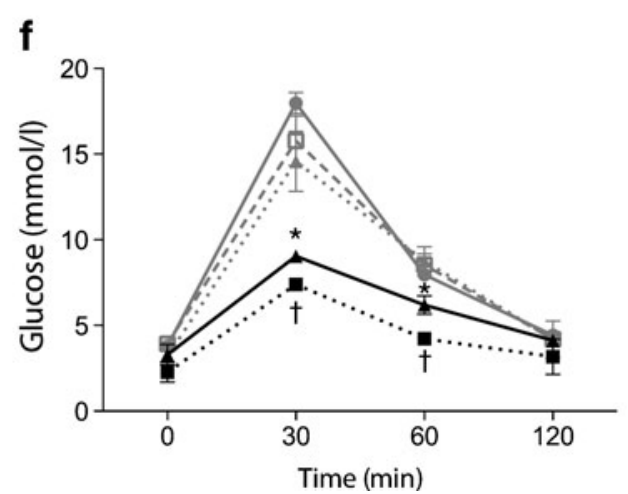


p21 $1^{\text {Cip-l- }}$ mice exhibited beta cell mass comparable with that of p21 ${ }^{\mathrm{Cip}+/+}$ mice (Fig. 5a and quantitative analysis in Fig. 5b). Compared with p $21^{C i p+/+}, c a A k t^{T g}$ mice demonstrated a sixfold increase in beta cell mass (Fig. 5a,b). Interestingly, the increase in beta cell mass observed in $c a A k t^{T g}$ was further enhanced in $c a A k t^{T g} / \mathrm{p} 21^{C i p+/-}$ mice (Fig. 5a,b), which suggests that a reduction of $\mathrm{p} 21^{\text {Cip }}$ in caAkt ${ }^{T g}$ mice promoted beta cell proliferation. Collectively, these data point to the role of $\mathrm{p} 21^{\mathrm{Cip}}$ as a negative regulator of the cell cycle that acts as a compensatory brake for beta cell expansion induced by Akt.

Deletion of one allele of $p 21^{\text {Cip }}$ in caAkt ${ }^{T g}$ mice enhances proliferation and survival Because we observed an enhanced beta cell mass in $c a A k t^{T g} / p 21^{C i p+/-}$ mice, we then analysed beta cell proliferation by Ki67 staining. We did not observe any difference in beta cell proliferation between $p 21^{\mathrm{Cip+/-}}, \mathrm{p} 21^{\mathrm{Cip-/-}}$ and $p 21^{\mathrm{Cip}+/+}$ mice (Fig. 6a). caAkt ${ }^{\mathrm{Tg}}$

a p21

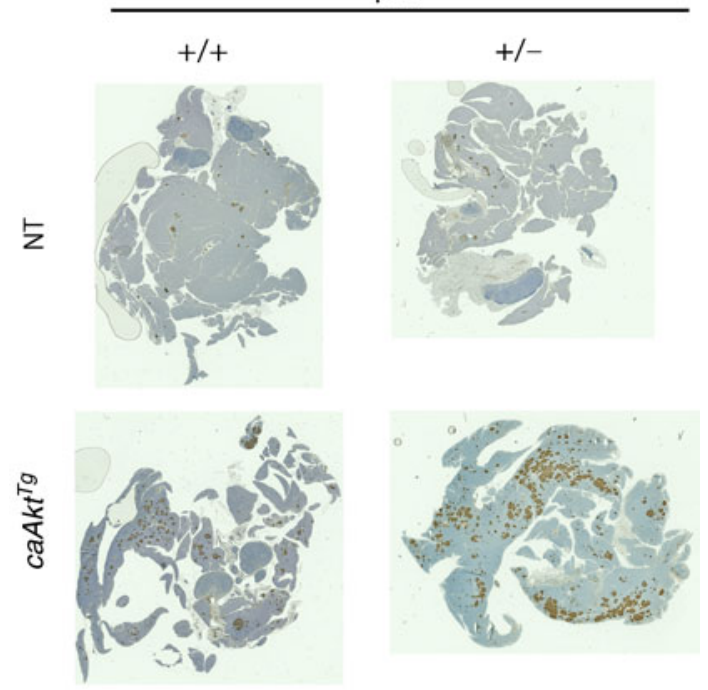

b

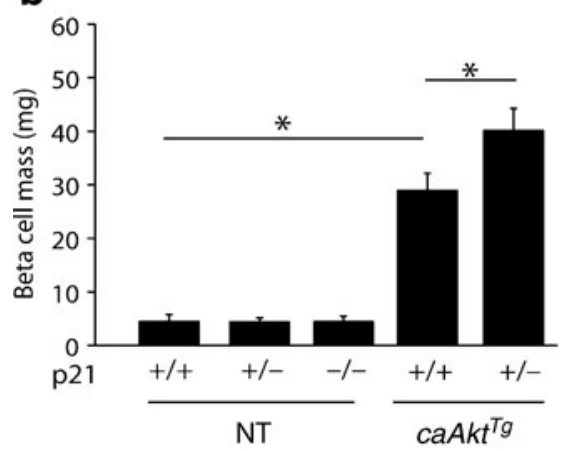

Fig. 5 Determination of pancreatic and islet morphology of $c a A k t^{T g}$ and $\mathrm{p} 21^{\text {Cip }}$ intercross. a Representative pancreatic morphology from mice with different genotypes stained for insulin (red) and counterstained with haematoxylin (blue). b Beta cell mass in 4-5-month-old progeny from $p 21^{-/} / c a A k t^{T g}$ intercross $(n \geq 3)$. Data are mean \pm SEM. ${ }^{*} p<0.05$. NT, non-transgenic
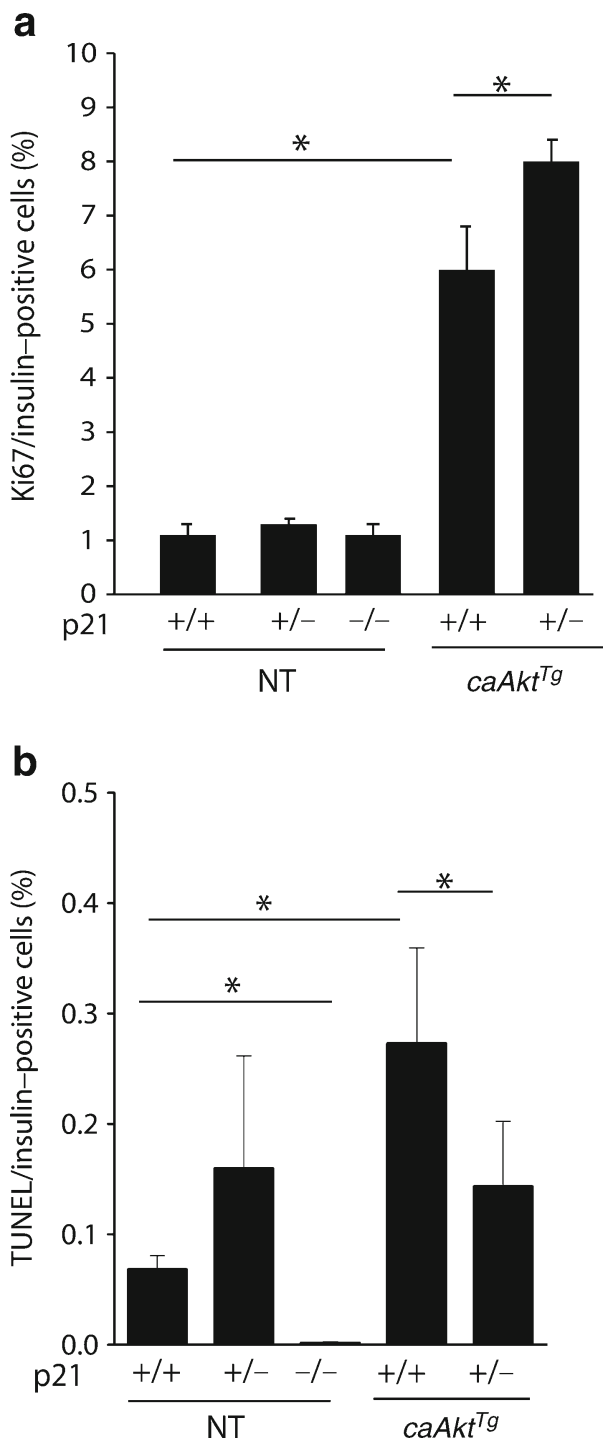

Fig. 6 Determination of beta cell proliferation and apoptosis among $c a A k t^{T g}$ and $\mathrm{p}_{21}{ }^{\mathrm{Cip}}$ intercrosses. a Proliferation index determined by percentage of Ki67-positive beta cells in $p 21^{C i p}$ and $c a A k t^{T g}$ intercross $(n \geq 3)$. TUNEL index determined by percentage of TUNEL-positive beta cells in $p 21^{C i p}$ and $c a A k t^{T g}$ intercross $(n \geq 3)$. Data are mean \pm SEM. ${ }^{*} p<0.05$. NT, non-transgenic

mice exhibited a sixfold increase in beta cell proliferation when compared with $\mathrm{p} 1^{\mathrm{Cip}+/+}$ mice (Fig. 6a). Interestingly, $c a A k t^{T g} / p 21^{C i p+/-}$ mice showed enhanced proliferation compared with $c a A k t^{T g}$, which suggests that deletion of one allele of $p 21^{\text {Cip }}$ augments the proliferative response in $c a A k t^{T g}$ mice. Given the role of $\mathrm{p} 21^{C i p}$ in cell survival [38], we also assessed cell death. TUNEL staining analysis showed that $c a A k t^{T g}$ mice have increased cell death compared with $p 21^{\mathrm{Cip}+/+}$ control mice (Fig. 6b). However, $\mathrm{caAkt}^{T g} / \mathrm{p} 21^{C i p+/-}$ mice exhibited less apoptosis compared with $c a A k t^{T g}$ mice, indicating that $\mathrm{p} 21^{C i p}$ enhances survival in conditions where there is activation of Akt signalling. Altogether, our data suggest that $\mathrm{p} 21^{\mathrm{Cip}}$ levels modulate the 
proliferative and survival responses induced by overexpression of Akt in pancreatic beta cells.

\section{Discussion}

The present study evaluated the mechanisms involved in the regulatory effect of $\mathrm{p} 21^{\mathrm{Cip}}$ on proliferation induced by activation of Akt signalling in beta cells. We have shown that Akt activation increases p $21^{\text {Cip }}$ levels at least in part by increased transcription and regulation of protein stability. We have also shown that the subcellular localisation of p2 $1^{\text {Cip }}$ is altered in both MIN6 ${ }^{\text {caAkt }}$ cells and beta cells of $c a A k t^{T g}$ mice. The in vivo experiments using Akt transgenic mice suggest that even though the CDK4/cyclin D complex is formed, increased $\mathrm{p} 21^{\mathrm{Cip}}$ levels exert a compensatory brake rather than increasing the assembly of the complex. These and published studies performed on $p 21^{C i p}$-null mice [15] suggest that reduction of $\mathrm{p} 21^{\text {Cip }}$ levels is not sufficient to enhance beta cell proliferation. Instead, decreased $\mathrm{p} 21^{\mathrm{Cip}}$ levels could favour beta cell cycle progression in conditions where there is increase in proliferation, such as in $c a A k t^{T g}$ mice. Therefore, our data also suggest that $\mathrm{p} 21^{\text {Cip }}$ could play an important role in the adaptation of beta cells in conditions where there is need for increased proliferation, as in conditions of insulin resistance.

The current studies show that $\mathrm{p} 21^{\mathrm{Cip}}$ protein levels were elevated in cells and islets with enhanced Akt signalling, and this elevation results in part by enhanced transcription and increased protein stability. The actinomycin D experiments show that the half-life of $p 21^{C i p}$ mRNA was significantly reduced in MIN6 $6^{\text {caAkt }}$ cells supporting the concept that transcriptional regulation is the major mechanism by which $p 21^{\text {Cip }}$ RNA expression is increased by Akt. Previous studies have demonstrated that the tumour protein p53 and forkhead box O (FOXO) transcription factors are involved in $p 21^{\text {Cip }}$ transcription in different systems [39-43]. Akt could modulate transcriptional regulation of $\mathrm{p} 21^{\mathrm{Cip}}$ by regulation of these transcription factors. Therefore, it is of future interest to test this possibility in vitro using promoter reporter assays. In addition to transcriptional regulation, treatment of both MIN6 cells and islets with CHX showed that the decay of $p 21^{C i p}$ was slowed in cells overexpressing a constitutively active Akt mutant. Thus, it appears that Akt also regulates $\mathrm{p} 21^{\text {Cip }}$ levels by increasing its protein stability. Our observation showing an increase in p $21^{\text {Cip }}$ stability is consistent with other studies showing that $\mathrm{p} 21^{\mathrm{Cip}}$ is directly phosphorylated by Akt, resulting in increased protein stability and cytoplasmic localisation [44-46]. In accordance with this finding, we also observed increased cytoplasmic localisation of $\mathrm{p} 21^{\text {Cip }}$ in cells with enhanced Akt signalling. Conceivably, restriction of $\mathrm{p} 21^{\text {Cip }}$ to the cytosol could limit its effect on cell cycle inhibition. However, the increased fraction of CDK4 bound to $\mathrm{p} 21^{\mathrm{Cip}}$ sequestered in cytoplasm could be, in part, a mechanism to indirectly limit unrestricted cell cycle progression in cells with activation of Akt. In addition to the effects on cell cycle progression, cytoplasmic $\mathrm{p} 21^{\mathrm{Cip}}$ protects against apoptosis in tumoural cells $[38,47]$. In contrast to this view, our results show that decreased p21 Cip levels in beta cells with gain of Akt function augment survival. These results are intriguing and perhaps suggest that the function of cytoplasmic $\mathrm{p} 21^{\mathrm{Cip}}$ in conditions of increased Akt activity could vary in vivo and be tissue specific. While the biological significance of elevated $\mathrm{p} 21^{\text {Cip }}$ levels and cytoplasmic localisation by Akt is still unclear, it is conceivable that this alteration may serve as a compensatory mechanism to prevent unrestricted proliferation.

An increasing body of evidence suggests that $\mathrm{p} 21^{\mathrm{Cip}}$ may act as a positive regulator of the cell cycle that is transiently induced during $\mathrm{G}_{1}-\mathrm{S}$ progression as a result of mitogenic stimuli. Therefore, it was unclear whether $\mathrm{p} 21^{\text {Cip }}$ was repressing beta cell cycle progression by inhibition of cyclin E/CDK2 complex or promoting proliferation by activation of CDK4. To test this in vivo, we crossed caAkt ${ }^{T g}$ mice with $p 21^{C i p}$-deficient mice. These experiments have shown that decreased $\mathrm{p} 21^{\text {Cip }}$ levels enhanced beta cell mass in $c a A k t^{T g}$ mice by increasing proliferation and enhancing survival. The changes in proliferation suggest that increased $\mathrm{p} 21^{\mathrm{Cip}}$ levels in $c a A k t^{T g}$ mice could serve as a compensatory brake to prevent unrestricted proliferation. These results are in contrast to the normal beta cell mass and proliferation observed $p 21^{C i p}$-deficient mice [48] and suggest that suppression of $\mathrm{p} 21^{\text {Cip }}$ levels is not sufficient to drive beta cell proliferation during basal conditions but could favour cell cycle progression during proliferative conditions, such as those observed in insulin-resistant states. It would be interesting to test the adaptation of $p 21^{C i p}$-deficient mice in states of insulin resistance induced by high-fat feeding. This experiment was recently performed, but the beta cell proliferative response was not determined [48].

Metabolic characterisation of the $c a A k t^{T g} / p 21^{C i p}$ intercross showed that deletion of $p 21^{C i p}$ resulted in additional alterations in carbohydrate metabolism. More specifically, reduction in $\mathrm{p} 21^{\mathrm{Cip}}$ expression resulted in further increases in insulin levels and improvement in glucose tolerance on the $\mathrm{caAkt}^{T g}$ background. Interestingly, we observed that $p 21^{C i p}$-deficient mice exhibited increased insulin sensitivity both on the non-transgenic or $c a A k t^{T g}$ background (data not shown). Therefore, it is likely that the increased insulin levels and improved glucose tolerance resulted predominantly from increases in beta cell mass. The changes in insulin sensitivity observed in these studies are intriguing and it is possible that alterations in adiposity in $p 21^{C i p}$-null mice could play a role in peripheral insulin sensitivity [48, 49]. Conflicting results in adiposity in $\mathrm{p} 21^{\mathrm{Cip}}$-null mice have 
been reported, and it is unclear whether the effect of this cell cycle inhibitor on adiposity during basal conditions is similar to that observed in mice exposed to high-fat feeding.

The importance of $\mathrm{p} 21^{\mathrm{Cip}}$ in regulation of the beta cell cycle is complex. Here, we have demonstrated that Akt increases $\mathrm{p} 21^{\text {Cip }}$ levels by modulating its protein stability and association with CDK4 and CDK2. In addition, we have demonstrated that the changes in $\mathrm{p} 21^{\mathrm{Cip}}$ induced by Akt have a significant impact on regulation of beta cell mass, proliferation and survival. These data suggest that $\mathrm{p} 21^{\text {Cip }}$ levels could play an important role in inhibiting cell cycle progression in beta cells during proliferative responses. Thus, deregulation of p $21^{\text {Cip }}$ could limit the adaptation of beta cells to insulin resistance or states of beta cell regeneration.

\begin{abstract}
Acknowledgements We acknowledge the MDRTC Cell and Molecular Biology Core (P60DK020572) and the Morphology Core at the University of Michigan Cancer Center for their services.
\end{abstract}

Funding This work was supported by National Institutes of Health Grant DK-073716, DK084236 (to E. Bernal-Mizrachi), research grant from The Juvenile Diabetes Research Foundation and a Career Development Award from the American Diabetes Association (to E. BernalMizrachi). E. U. Alejandro was supported by an NIH training grant (2T32DK071212-06).

Contribution statement EUA and AS performed experiments, analysed data and wrote/edited the manuscript. MB-R, JOS, BG, AYC, LR, DJB, AW, APG and LE performed experiments, analysed data and edited the manuscript. EB-M conceived the study and edited the manuscript. All the authors approved the final version to be published.

Duality of interest The authors declare that there is no duality of interest associated with this manuscript.

\section{References}

1. Dor Y, Brown J, Martinez OI, Melton DA (2004) Adult pancreatic beta-cells are formed by self-duplication rather than stem-cell differentiation. Nature 429:41-46

2. Lu Y, Herrera PL, Guo Y et al (2004) Pancreatic-specific inactivation of IGF-I gene causes enlarged pancreatic islets and significant resistance to diabetes. Diabetes 53:3131-3141

3. Ueki K, Okada T, Hu J et al (2006) Total insulin and IGF-I resistance in pancreatic beta cells causes overt diabetes. Nat Genet 38:583-588

4. Okada T, Liew CW, Hu J et al (2007) Insulin receptors in beta-cells are critical for islet compensatory growth response to insulin resistance. Proc Natl Acad Sci USA 104:8977-8982

5. Hugl SR, White MF, Rhodes CJ (1998) Insulin-like growth factor I (IGF-I)-stimulated pancreatic beta-cell growth is glucosedependent. Synergistic activation of insulin receptor substratemediated signal transduction pathways by glucose and IGF-I in INS-1 cells. J Biol Chem 273:17771-17779

6. Withers DJ, Gutierrez JS, Towery H et al (1998) Disruption of IRS-2 causes type 2 diabetes in mice. Nature 391:900-904
7. Withers DJ, Burks DJ, Towery HH, Altamuro SL, Flint CL, White MF (1999) Irs-2 coordinates Igf-1 receptor-mediated beta-cell development and peripheral insulin signalling. Nat Genet 23:32-40

8. Hennige AM, Burks DJ, Ozcan U et al (2003) Upregulation of insulin receptor substrate- 2 in pancreatic beta cells prevents diabetes. J Clin Invest 112:1521-1532

9. Lingohr MK, Buettner R, Rhodes CJ (2002) Pancreatic beta-cell growth and survival - a role in obesity-linked type 2 diabetes? Trends Mol Med 8:375-384

10. Lingohr MK, Dickson LM, Wrede CE, McCuaig JF, Myers MG, Rhodes CJ (2003) IRS-3 inhibits IRS-2-mediated signaling in pancreatic beta-cells. Mol Cell Endocrinol 204:85-99

11. Tuttle RL, Gill NS, Pugh W et al (2001) Regulation of pancreatic beta-cell growth and survival by the serine/threonine protein kinase Akt1/PKBalpha. Nat Med 7:1133-1137

12. Bernal-Mizrachi E, Wen W, Stahlhut S, Welling CM, Permutt MA (2001) Islet beta cell expression of constitutively active Akt1/PKB alpha induces striking hypertrophy, hyperplasia, and hyperinsulinemia. J Clin Invest 108:1631-1638

13. Garofalo RS, Orena SJ, Rafidi K et al (2003) Severe diabetes, agedependent loss of adipose tissue, and mild growth deficiency in mice lacking Akt2/PKB beta. J Clin Invest 112:197-208

14. Cho H, Mu J, Kim JK et al (2001) Insulin resistance and a diabetes mellitus-like syndrome in mice lacking the protein kinase Akt2 (PKB beta). Science 292:1728-1731

15. Fatrai S, Elghazi L, Balcazar $N$ et al (2006) Akt induces $\beta$-cell proliferation by regulating cyclin D1, cyclin D2, and p21 levels and cyclin-dependent kinase-4 activity. Diabetes 55:318-325

16. Rane SG, Dubus P, Mettus RV et al (1999) Loss of Cdk4 expression causes insulin-deficient diabetes and $\mathrm{Cdk} 4$ activation results in beta-islet cell hyperplasia. Nat Genet 22:44-52

17. Tsutsui T, Hesabi B, Moons DS et al (1999) Targeted disruption of CDK4 delays cell cycle entry with enhanced p27(Kip1) activity. Mol Cell Biol 19:7011-7019

18. Malumbres M, Sotillo R, Santamaria D et al (2004) Mammalian cells cycle without the D-type cyclin-dependent kinases Cdk4 and Cdk6. Cell 118:493-504

19. Kushner JA, Ciemerych MA, Sicinska E et al (2005) Cyclins D2 and D1 are essential for postnatal pancreatic $\beta$-cell growth. Mol Cell Biol 25:3752-3762

20. Chang F, McCubrey JA (2001) P21(Cip1) induced by Raf is associated with increased Cdk4 activity in hematopoietic cells. Oncogene 20:4354-4364

21. LaBaer J, Garrett MD, Stevenson LF et al (1997) New functional activities for the p21 family of CDK inhibitors. Genes Dev $11: 847-862$

22. Waga S, Hannon GJ, Beach D, Stillman B (1994) The p21 inhibitor of cyclin-dependent kinases controls DNA replication by interaction with PCNA. Nature 369:574-578

23. Weiss RH, Joo A, Randour C (2000) p21(Waf1/Cip1) is an assembly factor required for platelet-derived growth factor-induced vascular smooth muscle cell proliferation. J Biol Chem 275:10285-10290

24. Kavurma MM, Khachigian LM (2004) Vascular smooth muscle cell-specific regulation of cyclin-dependent kinase inhibitor p21 (WAF1/Cip1) transcription by $\mathrm{Sp} 1$ is mediated via distinct cisacting positive and negative regulatory elements in the proximal p21(WAF1/Cip1) promoter. J Cell Biochem 93:904-916

25. Kavurma MM, Khachigian LM (2003) Sp1 inhibits proliferation and induces apoptosis in vascular smooth muscle cells by repressing p21WAF1/Cip1 transcription and cyclin D1-Cdk4-p21WAF1/Cip1 complex formation. J Biol Chem 278:32537-32543

26. Georgia S, Bhushan A (2006) p27 Regulates the transition of betacells from quiescence to proliferation. Diabetes 55:2950-2956

27. Rachdi L, Balcazar N, Elghazi L et al (2006) Differential effects of p27 in regulation of beta-cell mass during development, neonatal period, and adult life. Diabetes 55:3520-3528 
28. Uchida T, Nakamura T, Hashimoto $\mathrm{N}$ et al (2005) Deletion of Cdkn1b ameliorates hyperglycemia by maintaining compensatory hyperinsulinemia in diabetic mice. Nat Med 11:175-182

29. Cozar-Castellano I, Haught M, Stewart AF (2006) The cell cycle inhibitory protein $\mathrm{p} 21 \mathrm{cip}$ is not essential for maintaining beta-cell cycle arrest or beta-cell function in vivo. Diabetes 55:3271-3278

30. Yang J, Zhang W, Jiang W et al (2009) P21 cip-overexpression in the mouse beta cells leads to the improved recovery from streptozotocin-induced diabetes. PLoS One 4:e8344

31. Agudo J, Ayuso E, Jimenez V et al (2008) IGF-I mediates regeneration of endocrine pancreas by increasing beta cell replication through cell cycle protein modulation in mice. Diabetologia 51:1862-1872

32. Cozar-Castellano I, Weinstock M, Haught M, Velázquez-Garcia S, Sipula D, Stewart AF (2006) Evaluation of beta-cell replication in mice transgenic for hepatocyte growth factor and placental lactogen: comprehensive characterization of the G1/S regulatory proteins reveals unique involvement of p21cip. Diabetes 55:70-77

33. Balcazar N, Sathyamurthy A, Elghazi L et al (2009) mTORC1 activation regulates beta-cell mass and proliferation by modulation of cyclin D2 synthesis and stability. J Biol Chem 284(12):7832-7842

34. Bernal-Mizrachi E, Wice B, Inoue H, Permutt MA (2000) Activation of serum response factor in the depolarization induction of Egr-1 transcription in pancreatic islet beta-cells. J Biol Chem 275:25681-25689

35. Cozar-Castellano I, Harb G, Selk K et al (2008) Lessons from the first comprehensive molecular characterization of cell cycle control in rodent insulinoma cell lines. Diabetes 57:3056-3068

36. Alejandro EU, Johnson JD (2008) Inhibition of Raf-1 alters multiple downstream pathways to induce pancreatic beta-cell apoptosis. J Biol Chem 283:2407-2417

37. Child ES, Mann DJ (2006) The intricacies of p 21 phosphorylation: protein/protein interactions, subcellular localization and stability. Cell Cycle 5:1313-1319

38. Cmielova J, Rezacova M (2011) p21(Cip1/Waf1) protein and its function based on a subcellular localization. J Cell Biochem 112:3502-3506
39. Herold S, Wanzel M, Beuger V et al (2002) Negative regulation of the mammalian UV response by Myc through association with Miz-1. Mol Cell 10:509-521

40. Seoane J, Le HV, Massague J (2002) Myc suppression of the $\mathrm{p} 21$ (Cip1) Cdk inhibitor influences the outcome of the p53 response to DNA damage. Nature 419:729-734

41. Wu S, Cetinkaya C, Munoz-Alonso MJ et al (2003) Myc represses differentiation-induced p21CIP1 expression via Miz-1-dependent interaction with the $\mathrm{p} 21$ core promoter. Oncogene 22:351-360

42. Seoane J, Le HV, Shen L, Anderson SA, Massague J (2004) Integration of Smad and forkhead pathways in the control of neuroepithelial and glioblastoma cell proliferation. Cell 117:211223

43. Evans-Anderson HJ, Alfieri CM, Yutzey KE (2008) Regulation of cardiomyocyte proliferation and myocardial growth during development by FOXO transcription factors. Circ Res 102:686-694

44. Li Y, Dowbenko D, Lasky LA (2002) AKT/PKB phosphorylation of $\mathrm{p} 21 \mathrm{Cip} / \mathrm{WAF} 1$ enhances protein stability of p21Cip/WAF1 and promotes cell survival. J Biol Chem 277:11352-11361

45. Zhou BP, Liao Y, Xia W, Spohn B, Lee MH, Hung MC (2001) Cytoplasmic localization of p21Cip1/WAF1 by Akt-induced phosphorylation in HER-2/neu-overexpressing cells. Nat Cell Biol $3: 245-252$

46. Xia W, Chen JS, Zhou X et al (2004) Phosphorylation/cytoplasmic localization of $\mathrm{p} 21 \mathrm{Cip} 1 / \mathrm{WAF} 1$ is associated with HER2/neu overexpression and provides a novel combination predictor for poor prognosis in breast cancer patients. Clin Cancer Res 10:3815-3824

47. Coqueret $\mathrm{O}(2003)$ New roles for $\mathrm{p} 21$ and $\mathrm{p} 27$ cell-cycle inhibitors: a function for each cell compartment? Trends Cell Biol 13:65-70

48. Inoue N, Yahagi N, Yamamoto $T$ et al (2008) Cyclin-dependent kinase inhibitor, p21WAF1/CIP1, is involved in adipocyte differentiation and hypertrophy, linking to obesity, and insulin resistance. J Biol Chem 283:21220-21229

49. Naaz A, Holsberger DR, Iwamoto GA, Nelson A, Kiyokawa H, Cooke PS (2004) Loss of cyclin-dependent kinase inhibitors produces adipocyte hyperplasia and obesity. FASEB J 18:1925-1927 